\title{
Evaluation of Mercury, Arsenic, Lead and Cadmium in River Water Intended for Human Consumption as a Consequence of Mining Activities.
}

\author{
ANGELICA ZEA ( $\square$ azea@ups.edu.ec ) \\ UNIVERSIDAD POLITECNICA SALESIANA https://orcid.org/0000-0002-6293-0735 \\ DIEGO ANGAMARCA \\ UNIVERSIDAD POLITECNICA SALESIANA
}

LEIVER VALAREZO

UNIVERSIDAD POLITECNICA SALESIANA

\section{Article}

Keywords: toxic effects, toxic elements, heavy metals, mining, public health

Posted Date: February 17th, 2022

DOI: https://doi.org/10.21203/rs.3.rs-1351577/v1

License: (c) (i) This work is licensed under a Creative Commons Attribution 4.0 International License. Read Full License 


\section{Abstract}

The vast majority of mineral deposits that exist in Ecuador are located in the Andean zone, and in this sense it is important to carry out permanent monitoring of heavy metals present in the soil, and mainly in the water, especially in places where One of its economic activities is mining, with this background this work is based on monitoring potentially toxic elements: Mercury, Arsenic, Lead and Cadmium, these being the main ones that cause damage to the health of the population due to their toxic effects, the monitoring of these toxic elements is carried out in the upper basin of the Santa Rosa River, this place is selected due to the mining activity that exists in the Santa Rosa canton, province of El Oro-Ecuador, 10 sampling points are selected to the along 81 kilometers of the river basin and samples are included in the water plant, the same one that is destined for human consumption, the analysis of the samples was carried out by E Atomic Emission Spectroscopy with Inductive Coupling Plasma (ICP-AES), the results obtained show contamination of the water resource, according to the United States Environmental Protection Agency (EPA), and INEN 1108, World Health Organization (WHO), and the applied surveys show the use of this water in different activities, both domestic and agricultural, therefore the objective of this work is to raise awareness in the community in general about the importance of taking care of the water resource and taking all preventive measures for public health.

\section{Introduction}

Human activities have always interacted with the environment either to a greater or lesser extent, this is due to the large growth of the world population, causing a greater increase in the needs for resources and food, generating damage to the environment, some irreversible, such as water, soil or air pollution, depletion of non-renewable resources, generation of the greenhouse effect, etc. (Pastor, 2017).

The mining and metallurgical sector is the largest contributor to the economy, for the material needs of the industrial world, and is also of great importance for the development and growth of developing countries. Many countries take advantage of mineral resources, since they contribute positively to economic growth (Almera et al., 2011).

Due to metallic mining there is uncontrolled and irresponsible exploitation, causing the depletion of natural resources, the sometimes irreversible disappearance of a large number of species of fauna and flora and the degradation of natural ecosystems (Colombia, 2015).

Unlike other Latin American countries, Ecuador has not implemented a dynamic of promoting mining activity in which the aim is to make a high profitability visible through regulations. This practice has been carried out in the region since the 1980s, and although it has meant the largest growth of the mining sector in emerging economies in the last 15 years, it has generated very important socio-environmental conflicts. It should be noted that this does not happen in Ecuador due to the legal regulations in force, whose main characteristic is to recognize nature as a subject of rights (Bebbington, 2010).

The most significant impact of mining is the effect it has on the availability and quality of water resources, since when materials such as tailings, debris and leachates are exposed to oxygen and water, an acid is created that dissolves metals and other contaminants found in mining materials and forms an acid solution with a high sulfate content rich in metals (including high concentrations of copper, cadmium, lead, zinc, arsenic, etc.), which is generally dumped directly into the riverbed without receiving any prior treatment. ), which is generally dumped directly into the riverbed without receiving any prior treatment, thus causing contamination of the water resource due to the presence of a high content of heavy metals (Latorre \& Tovar, 2017). According to the (EPA, 2017)." Metallic elements with high 
density (e.g., chromium, mercury, arsenic, cadmium and lead); can be toxic to living things in small concentrations and tend to accumulate in the food chain.".According to the (EPA, 2017). Metals such as mercury ( $\mathrm{Hg})$, lead (Pb), arsenic (As) and cadmium (Cd) are included among the 13 priority pollutants on the list along with others such as antimony, beryllium, chromium, copper, nickel, silver, selenium, thallium, zinc.

In rivers, discharges of contaminants resulting from mining activities negatively affect all forms of life, causing severe environmental impacts and damage to human health due to the ingestion of contaminated water and food. Table I shows the maximum admissible concentration levels, and the consequences on health, caused by excess traces of heavy metals as recorded by Ecuadorian legislation (Oviedo Anchundia, Moina Quimi, Naranjo Moran, \& Barcos Arias, 2017)

Therefore, there is a need to monitor heavy metals in the water of the upper Santa Rosa River Basin, since this is an area where the main economic activity is mining, and knowledge of this will allow us to establish the concentrations of mercury, cadmium, arsenic and lead in the upper Santa Rosa River basin, arsenic and lead in the upper basin of the Santa Rosa River because this water is used by the drinking water plant of the Santa Rosa canton, which supplies $85 \%$ of its population. It is therefore in the interest of Public Health to know if the quality of the water consumed complies with the established norm and is apt for human consumption.

The World Health Organization (OMS), the U.S. Environmental Protection Agency (EPA), and the Ecuadorian Technical Standard (INEN 1108) establish safety requirements for more than 80 contaminants that may be in water and whose concentrations above the permissible limit represent a high risk to human health, according to the OMS.

\section{Materials And Methods}

For the execution of this project, the type of chemical elements to be analyzed was selected based on those that were considered important in the river water pollution caused by mining, among the elements that were selected were: mercury, cadmium, lead and arsenic. (Oviedo-Anchundia et al., 2017).

The river water samples were collected in the upper basin of the Santa Rosa River, located in the Province of El Oro, southwestern Ecuador, to be transported to the city of Cuenca for their respective analyses.

At each sample collection point, and with the help of GPS we took the coordinates of the place; in total there were 10 sampling points along the entire length of the upper Santa Rosa River basin, the length of the basin which is 80.18 $\mathrm{km}$, taking into account the following conditions: agricultural area, mining area and in the supply area of the drinking water plant.

With the help of the geographic information system, the study area was georeferenced using ArcGIS software as shown in Fig. 1.

Water sampling at the different monitoring points was carried out based on the steps stipulated in INEN 2169:2013 AND INEN 2176:2013 standards on "WATER. WATER QUALITY. SAMPLING. SAMPLE HANDLING AND CONSERVATION".

The sampling points are described below for heavy metals:

Sample 1 (m1): Santa Rosa river site el Guayabo.

Sample 2 (m2): El Panteón Creek, 
Sample 3 (m3): the junction of El Panteón Creek with the Santa Rosa river.

Sample 4 (m4): kilometers downstream from el Guayabo site.

Sample 5 (m5): kilometers downstream of the Guayabo site.

Sample 6 (m6): Playón-Parroquia Torata.

Sample 7 (m7): Limón Playa-Parroquia Torata.

Sample 8 (m8): Drinking water catchment-Parroquia.

Sample 9 (m9): Drinking water plant: distribution tank.

Sample 19 (m10): house faucet in Cantón Santa Rosa.

After sampling, we proceeded with the physicochemical tests of the water samples; the containers were previously washed with $10 \%$ diluted nitric acid to eliminate any type of substance that could interfere with the tests; the chemical analysis was carried out in the Atomic Emission Spectroscopy with Inductively Coupled Plasma (ICP-AES) equipment; the results were obtained in ppm.

On the other hand, in order to know the main uses of the Santa Rosa river water, community surveys were conducted. The survey was designed with questions focused on the use of river water directed to the inhabitants of the upper Santa Rosa River basin. The sample size for the survey was based on the total population of the upper Santa Rosa River basin, which resulted in an approximate number of 349:

$$
\operatorname{NumberofSurveys}(\mathrm{n})=\frac{\mathrm{N} * \mathrm{Z}_{\alpha}^{2}{ }^{*} \mathrm{p} * \mathrm{q}}{\mathrm{e}^{2 *}(\mathrm{~N}-1)+\mathrm{Z}_{\alpha}^{2} \mathrm{p}^{*} \mathrm{q}}
$$

Where $\mathrm{N}=$ size of the population or universe present in illustration (8); $\mathrm{e}=$ maximum accepted estimation error; $\mathrm{Z}=$ statistical parameter that depends on the confidence level which is presented in table (3) with its score; $p=$ probability of occurrence of the studied event (success) and q = probability of non-occurrence of the studied event (Rodriguez, 2012).

\section{Number of Surveys}

$$
\text { NumberofSurveys }(\mathrm{n})=\frac{3900 * 1.96^{2 * 0.5 * 0.5}}{0.05^{2 *}(3900-1)+1,96^{2} * 0.5 * 0.5}=348.47 \approx 349
$$

Data tabulation was performed through the application of statistics using Excel. Once the results were obtained, they were compared with the INEN 1108 standard and book VI Annex 1 of the TULSMA, to achieve the objective and determine whether or not there is contamination from mining activity in the upper Santa Rosa river basin.

\section{Results}

Sampling for the monitoring of heavy metals was carried out at 10 points, the first 8 in the river water of the upper Santa Rosa River basin, and samples 9 and 10 correspond to the treatment plant and household faucet. It is important to make this distinction because, according to the regulations used, the criteria for permissible limits are different for river water and water used for consumption. 


\section{Results of samples obtained in the upper Santa Rosa River basin:}

The results of the monitoring of heavy metals in the river water samples obtained in the upper Santa Rosa River basin were compared with the respective regulations: EPA, WHO, INEN.

The values of the analyses obtained for heavy metals in river water in the upper Santa Rosa River basin, compared with the respective regulations, indicate that mercury exceeded the maximum permissible limits in samples 1 and 2 , and cadmium in samples 2 to 5 exceeded the maximum permissible limits. This contamination could be due to the fact that at sampling points 1 and 2 there are mining concessions that spill leachate into the Santa Rosa River without any prior treatment.

Arsenic, according to the respective regulations, is above the permissible limit value in sample 2.

\section{Results of the samples obtained at the Drinking Water Treatment Plant}

The heavy metals of the samples taken at the drinking water plant and at the household faucet corresponding to samples 9 and 10 from the Santa Rosa canton respectively, sample 9 refers to the sample taken at the treatment plant, and sample 10 refers to the sample taken at the household faucet immediately after drinking water treatment, These values are compared with the results obtained from the respective monitoring of heavy metals Lead, Arsenic, Cadmium and Mercury, as shown in Table 3.

The results of the samples obtained at the drinking water plant for water entering without any prior treatment and for treated water were compared with the NTE INEN 1108 standard.

Sample 9, water from the drinking water treatment plant, showed that lead, arsenic, cadmium, and mercury comply with the maximum allowable limits established in the standard.

Sample 10, which corresponds to treated water obtained at the drinking water plant, whose values exceed the maximum limits of arsenic, cadmium and mercury allowed for drinking water, which can cause various health effects on the inhabitants of the city of Santa Rosa.

Comparison of the results of heavy metal analysis compared to previous years in the upper Santa Rosa River basin in the Quebrada El Panteón sector - El Guayabo sector.

the upper basin of the Santa Rosa River, analyses of heavy metals in the water have been conducted by the public drinking water company of the Santa Rosa canton (EMAPA SR). Table 4 shows the values of the analyses from 2012 to 2021 in a specific point such as the Quebrada El Panteón-Sector El Guayabo; in this place, mine wastewater is discharged without any prior treatment, which joins the Santa Rosa River.

Mercury in Quebrada El Panteón from 2012 to 2018 complied with the maximum permissible limits, but in 2019 it exceeded the permissible limits with a value of $0.0114 \mathrm{mg} / \mathrm{l}$. According to our analysis, which is from 2021, mercury with a value of $0.00876 \mathrm{mg} / \mathrm{l}$ exceeded the limit stipulated in the standard.

\section{Comparison of heavy metal results for samples 9 and 10:}

Table 5 shows the results of heavy metals from 2012 to 2021, another important point of analysis, since the drinking water plant of the Santa Rosa canton supplies drinking water to $85 \%$ of its population, being essential to have water that meets the physical, chemical and microbiological parameters for the good of the public health of the population, in this case of the Santa Rosa community, one of the economic activities being mining. 
According to our analysis of the year 2021, arsenic with a value of $0.015 \mathrm{mg} / \mathrm{l}$ exceeds the permissible range established in the standard and is harmful to human health.

Lead in the drinking water plant the years 2012,2014,2016,2017, 2018 and 2019 are within the maximum permissible limits; but the years 2013 and 2015 exceeded the permissible limits. According to our analysis in the year 2021 lead with a value of $<0.001 \mathrm{mg} / \mathrm{l}$, complies with the maximum permissible limits.

According to our analysis that is the year 2021 cadmium with a value of $0.0106 \mathrm{mg} / \mathrm{l}$, exceeds the maximum permissible limit established in the standard.

Mercury from the year 2012 to 2019 in the drinking water plant complied with the maximum permissible limits established in the standard. According to our analysis in 2021 mercury with a value of $0.0471 \mathrm{mg} / \mathrm{l}$, exceeds the permissible ranges

\section{Results of the surveys applied to the Santa Rosa community on water use:}

A total of 349 surveys were conducted among the community living along the upper Santa Rosa River watershed, with the following results:

- $93 \%$ of the population living here uses river water and $7 \%$ does not use this water.

- $89 \%$ of the population has potable water in their homes and $11 \%$ does not have this service, so they use river water for their needs.

$-46 \%$ of the population uses river water for agriculture, $36 \%$ uses it for livestock and $18 \%$ for domestic activities.

- $89 \%$ of the population has potable water in their homes and $11 \%$ does not have this service, so they use river water for their needs.

\section{Discussion}

From the results obtained for the heavy metals analyzed, such as mercury, lead, cadmium and arsenic: mercury, lead, cadmium and arsenic, of the eight samples taken in the river water do not meet all samples with the maximum permissible limits in accordance with the provisions of the regulations, at the sampling points, The values that exceed the permissible limits can be related to anthropogenic activity, specifically mining activity in this area, since this contamination could be due to the fact that at sampling points 1 and 2 there are mining concessions that spill leachates into the Santa Rosa River without any prior treatment.

On the other hand, the two samples taken at the drinking water plant and the sample taken at the household faucet do not comply with the maximum permissible limits as established in the regulation on drinking water criteria given in the NTE INEN 1108 standard; this could be due to an accumulation of these heavy metals in the drinking water storage tanks.

From the above, it was determined that there is contamination of the water resources in the upper Santa Rosa River basin due to mining activity, especially in the El Guayabo sector, because this is where most of the mining concessions are located and discharge leachates into the river without any prior treatment, which is harmful to aquatic life, agriculture, livestock, and human health in the area; it was also found that there are heavy metals in the 
drinking water plant, which is harmful to the population of Santa Rosa canton that uses this water for human consumption.

Surveys conducted in the community living along the upper Santa Rosa River basin showed that most of the inhabitants have drinking water, but use the river water for domestic use without prior treatment, which would affect the health of the population. In addition, the river water is used for agriculture and livestock.

\section{Recommendations}

Based on the results and conclusions obtained in this investigation, some recommendations are suggested:

- - Prohibit the execution of mining activities, whether metallic or non-metallic, upstream of the drinking water catchment in the upper Santa Rosa River basin in order to avoid contamination of the water resource due to the presence of heavy metals.

- - Conduct periodic inspections of the mining concessions and verify compliance with the Environmental Management Plans in order to avoid contamination of the water resources in the upper Santa Rosa River basin.

- - It is recommended that the mining concessions located in the sector apply some type of treatment to eliminate heavy metals because, according to the analyses, there is a possible accumulation of mercury, arsenic, and cadmium in the drinking water storage tank, which would be harmful to human health because this water is intended for human consumption.

- - It is recommended that in future water quality monitoring studies, in addition to the routine physical-chemical and microbiological analyses, it is necessary to link the different economic activities that the community engages in to perform a water analysis that links the chemical parameters related to anthropogenic activity: if it handles and uses pesticides and is dedicated to crops, it is suggested that the chemical analyses include determination of pesticides; if the community is dedicated to mining, it is suggested that the routine analysis include heavy metals such as mercury; etc.

\section{References}

1. Allan, R., Forstner, U., \& Salomons, W. (1999). Environmental Impacts of Mining Activities. Environmental Impacts of Mining Activities. https://doi.org/10.1007/978-3-642-59891-3

2. Almera, J., Mitjans, I. Q., Cardellach, E., \& Ambientals, T. (2011). Impacto ambiental de las areas de mineria metálica: Aplicación de metodologías analíticas no destructivas al análisis geoquímico.

3. Ambiente, M. D. E. L., \& Gálvez, I. G. (2015). PROGRAMA DE REPARACIÓN AMBIENTAL Y SOCIAL PRAS Tema: (10) Identificación de las fases de la actividad minera que generan mayor cantidad de pasivos ambientales de origen minero, cuya reparación demande mayor cantidad de recursos Doc. $N^{\circ}$ : PRAS-GG-021. 10, 1-19.

4. Andaluz, I., Albareda, P., \& Mercedes, R. (2010). IV Congreso Ibérico de la Ciencia del Suelo,. 1996, 2010.

5. Andrés Arango Mendoza, J. (2014). PROYECTO DE MINERÍA DE ORO LA COLOSA, Identificación ambiental de la zona de explotación y sus Impactos JULIÁN ANDRÉS ARANGO MENDOZA TUTOR WILLIAM ÁNGEL SALAZAR Facultad de Estudios Ambientales y Rurales Maestría en Gestión Ambiental Bogotá Abril de 2014.

6. Antabe, R., Atuoye, K. N., Kuuire, V. Z., Sano, Y., Arku, G., \& Luginaah, I. (2017). Community health impacts of surface mining in the Upper West Region of Ghana: The roles of mining odors and dust. Human and Ecological Risk Assessment, 23(4), 798-813. https://doi.org/10.1080/10807039.2017.1285691

7. Arango Aramburo, Marcela; Olaya, Y. (2012). Problematica de los pasivos ambientales. 124-133. 
8. Armah, F. A., Luginaah, I., \& Obiri, S. (2012). Assessing environmental exposure and health impacts of gold mining in Ghana. Toxicological and Environmental Chemistry, 94(4), 786-798.

https://doi.org/10.1080/02772248.2012.667205

9. Ayala, F., \& Vadillo, Lu. (1989). Manual De Restauración De Terrenos Y Evaluación De Impactos Ambientales En Minería.

10. Bebbington, A. J. (2010). Mining, institutions and sustainability: disagreements and challenges. Anthropologica, 28(28), 53-84.

11. Burbano, X. (2011). Análisis de Contenido del Reglamento Ambiental para las Actividades Mineras en la República del Ecuador.

12. Casadiego Quintero, E., Gutiérrez Bayona, A. G., Herrera Lopez, M. Á., \& Páez Rojas, M. L. (2017). Manejo estratégico de la producción de residuos estériles de minería sustentable, utilizando prácticas mineras ecoeficientes en Colombia. Revista de Investigación Agraria y Ambiental, 8(2), 107-118. https://doi.org/10.22490/21456453.2035

13. Colombia, D. D. P. (2015). Un enfoque desde la vulneración de los Derechos Humanos.

14. Domínguez Andrade, J. M. (2013). La minería a gran escala en Ecuador: Una perspectiva de Desarrollo.

15. Ecuador, P. C. de la R. del. (2009). Reglamento de regimen especial de pequeña minería. 1-13.

16. Egas, G. C. (2009). Caracterización y evaluación de la Cuenca Alta del Río Santa Rosa. xx, 11.

17. ELAW. (2010). Vista General de la Actividad Minera y sus Impactos. In Guía para Evaluar ElAs de Proyectos Mineros (Vol. 130, Issues 3-4, pp. 295-302). https://doi.org/10.1127/1869-6155/2013/0130-0074

18. EPA. (2017). Terminos relacionados a ciencias ambientales.

19. Español, S. (2012). Biomédica Instituto Nacional de Salud. 3, 2004-2006.

20. Espín, D., Jarrín, J., \& Escobar, O. (2017). Manejo, gestión, tratamiento y disposición final de relaves mineros generados en el proyecto río blanco. Revista de Ciencias de Seguridad y Defensa, II(4), 1-12.

http://geo1.espe.edu.ec/wp-content/uploads/2018/01/Art1.pdf

21. EXA, S. (2015). Actividad Minera III: explotación y beneficio.

22. Falla Velásquez, N. R. (2012). Riesgos laborales en minería a gran escala en etapas de prospeccion - exploración de metales y minerales en la región sureste del Ecuador y propuesta del modelo de gestión de seguridad y salud ocupacional para empresas mineras en la provincia de Zamora Ch.

23. FLACSO. (2011). Comercialización minera.

24. González, C. (2011). Monitoreo de la calidad del agua. La Turbidez, 11.

25. Goyenola, G. (2007). Transparencia, color y turbidez. Guía Para La Utilización de Las Valijas Viajeras Transparencia, Etc, 2.

26. Gutierrez, J., Vega, J., \& Berrio, O. (2016). Generalidades de la Responsabilidad Social Corporativa Empresarial en la Gran Industria de Energía, Minería y Petróleo en Colombia *. 22, 28-47.

27. Herdoíza, D. L., Fierro-renoy, V., \& Fierro-renoy, C. (2017). Minería a Gran Escala: Una Nueva Industria para Ecuador. 67-91.

28. Juan Soria Carreras. (n.d.). Los Residuos Mineros.

29. Latorre, Á. M. L. R., \& Tovar, M. H. T. (2017). Explotación minera y sus impactos ambientales y en salud. El caso de Potosí en Bogotá. Saúde Em Debate, 41(112), 77-91. https://doi.org/10.1590/0103-1104201711207

30. Lopez Bravo, M., Santos Luna, J., Quezada Abad, C., Segura Osorio, M., \& Perez Rodriguez, J. (2016). Actividad minera y su impacto en la salud humana / The mining and its impact on human health. Ciencia Unemi, 9(17), 
92. https://doi.org/10.29076/issn.2528-7737vol9iss17.2016pp92-100p

31. Ministerio de Minería del Ecuador. (2016). Plan nacional de desarrollo del sector minero. 1-308.

32. Moffatt, J., \& Baker, P. (2013). Farmers, mining and mental health: The impact on a farming community when a mine is proposed. Rural Society, 23(1), 60-74. https://doi.org/10.5172/rsj.2013.23.1.60

33. Moreano Sandoval, F., Gómez Albán, J., Aguirre Carvajal, M., Arturo Chamorro, C., \& Vinueza Pasmiño, D. (2000). Minería, Minerales y Desarrollo Sustentable en Ecuador Introducción. 1-96.

34. Moreno C, B., Soto O, K., \& González R, D. (2015). El consumo de nitrato y su potencial efecto benéfico sobre la salud cardiovascular TT - Nitrate consumption and potential beneficial effect on cardiovascular health. Rev. Chil. Nutr, 42(2), 199-205.

35. Moschella, P. (2011). Impactos ambientales de la mineria aurifera y percepción local en la microcuenca Huacamayo, Madre de dios. Journal of Chemical Information and Modeling, 18(2), 159-167. https://doi.org/10.1056/NEJMc1611875

36. Mutti, D., Yakovleva, N., Vazquez-Brust, D., \& Di Marco, M. H. (2012). Corporate social responsibility in the mining industry: Perspectives from stakeholder groups in Argentina. Resources Policy, 37(2), 212-222. https://doi.org/10.1016/j.resourpol.2011.05.001

37. Nolasco, S. (2011). Impactos de la Minería Metálica en Centroamérica. 75. https://www.ocmal.org/wpcontent/uploads/2017/03/Impactos_de_la_Mineria_Metalica_en_Centroamerica.pdf

38. Oviedo-Anchundia, R., Moina-Quimí, E., Naranjo-Morán, J., \& Barcos-Arias, M. (2017). Contamination by heavy metals in the south of Ecuador associated to the mining activity. Revista Bionatura, 2(4), 437-441. https://doi.org/10.21931/RB/2017.02.04.5

39. Pastor, A. (2017). La evaluación de impacto ambiental en minería: Estudio Preliminar de Impacto Ambiental.

40. Protomastro, G. (2014). Refinación de Metales - Economía Circular y Minería Urbana.

41. Ramos-Ortega, L. M., Vidal, L. A., Sandra, V. Q., \& Saavedra-Díaz, L. (2010). Análisis de la contaminación microbiológica (coliformes totales y fecales) en la Bahía de Santa Marta, Caribe Colombiano. Acta Biologica Colombiana, 13(3), 87-98.

42. Rea Toapanta, A. R. (2017). Política minera y sostenibilidad ambiental en Ecuador. FIGEMPA: Investigación y Desarrollo, 1(2), 41-52. https://doi.org/10.29166/revfig.v1i2.68

43. Revisi, C. D. E., Ortiz, L. L., Grado, I. I., Auxiliar, P., \& Provincial, C. (2009). Contaminación del agua por nitratos: significación sanitaria. Archivo Médico de Camagüey, 13(2).

44. Rodríguez, E. B. (2012). Muestra y muestreo. Universidad Autonoma Del Estado de Hidalgo, 20.

45. Ronm, E., Law, E., \& Tute, I. N. (2000). Prevencion de la Contaminacion Minera: Propuesta de un Marco Común para las Américas (Issue January).

46. Sanchez Barrón, G. (2016). Ecotoxicología del cadmio: riesgo para la salud de la utilizacion de suelos ricos en cadmio. Facultad De Farmacia Universidad Complutense Trabajo, 23.

http://147.96.70.122/Web/TFG/TFG/Memoria/GARA SANCHEZ BARRON.pdf

47. Sandoval, F. (2001). La pequeña minería en el Ecuador. Mining, Minerals and Sustainable Development, 75. https://doi.org/10.1039/b203596k

48. Suarez, D. S. (2006). Conductividad Electrica Por El Método Electrométrico En Aguas. Ideam, 2.

49. Vásconez Carrasco, M., \& Torres León, L. (2018). Minería en el Ecuador: sostenibilidad y licitud. Revista Estudios Del Desarrollo Social: Cuba y América Latina, 6(2), 83-103.

50. Vasquez, E., \& Rojas, T. (2016). pH: Teoría y problemas. 
51. Vázquez, L. S., Leifsen, E., \& Delgado, A. D. V. (2017). Minería a gran escala en ecuador: Conflicto, resistencia y etnicidad. AIBR Revista de Antropologia Iberoamericana, 12(2), 169-192. https://doi.org/10.11156/aibr.120205

52. Velasco Betancourt, C. E. (2015). Contaminantes generados en la exploración y explotación minera, métodos de análisis y sus efectos ambientales Monografía previa a la obtención del título de Licenciado en Ciencias Quím.

53. Zorilla, C. (2013). La minería y sus impactos en el Ecuador. 4.

\section{Annexes}

Table I. Consequences on human health of exceeding the maximum permissible concentration (mca) limits for heavy metals in water for human consumption

\begin{tabular}{|lcl|}
\hline \multicolumn{2}{|l|}{ Maximum Allowable Concentration Values in Ecuador (MAC) } \\
\hline Heavy Metals mg/L & & Human health impact \\
\hline Arsenic (As) & 0.05 & Cutaneous manifestations, visceral cancers, vascular disease \\
\hline Cadmium (Cd) & 0.01 & Renal damage, actual impairment and carcinogenic effects \\
\hline Lead (Pb) & 0.05 & Brain teratogenicity, renal vascular and neuronal diseases. \\
\hline Mercury (Hg) & 0.001 & Rheumatoid arthritis and renal, vascular and neuronal diseases. \\
\hline Source: (Oviedo Anchundia, Moina Quimi, Naranjo Moran, \& Barcos Arias, 2017) \\
\hline
\end{tabular}

Table 2

comparison of water samples 1 to 8 obtained from the upper santa rosa river basin, with the water quality criteria established in the respective regulations.

\begin{tabular}{|c|c|c|c|c|c|c|c|c|c|c|c|}
\hline & EPA & OMS & $\begin{array}{l}\text { NTE } \\
\text { INEN } \\
1108\end{array}$ & $\mathrm{~m} 1$ & $\mathrm{~m} 2$ & m3 & $\mathrm{m} 4$ & $\mathrm{~m} 5$ & $\mathrm{~m} 6$ & $\mathrm{~m} 7$ & $\mathrm{~m} 8$ \\
\hline Lead & 0.01 & 0.01 & 0.01 & $<L D$ & $<L D$ & $<L D$ & $<L D$ & $<\mathrm{LD}$ & $<L D$ & $<L D$ & $<L D$ \\
\hline Arsenic & 0.05 & 0.01 & 0.01 & 0.004 & 0.0493 & 0.008 & 0.008 & 0.0093 & 0.0085 & 0.0154 & 0.02 \\
\hline Cadmium & 0.003 & 0.003 & 0.003 & 0.001 & 0.0075 & 0.022 & 0.022 & 0.0164 & $<L D$ & $<L D$ & $<\mathrm{LD}$ \\
\hline Mercury & 0.001 & 0.006 & 0.006 & 0.013 & 0.0088 & 0.001 & 0.001 & 0.0001 & 0.0009 & $<L D$ & $<L D$ \\
\hline
\end{tabular}

Units: $\mathrm{mg} / \mathrm{I}$ 
Table 3

results obtained from the analysis of heavy metals taken at the drinking water plant

\begin{tabular}{|llllll|}
\hline & EPA & OMS & NTE INEN 1108 & $\mathrm{m9}$ & $\mathrm{m} 10$ \\
\hline Plomo & 0.01 & 0.01 & 0.01 & $<\mathrm{LD}$ & $<\mathrm{LD}$ \\
\hline Arsénico & 0.05 & 0.01 & 0.01 & 0.00989 & 0.0155 \\
\hline Cadmio & 0.003 & 0.003 & 0.003 & $<\mathrm{LD}$ & 0.0106 \\
\hline Mercurio & 0.001 & 0.006 & 0.006 & 0.0478 & 0.0471 \\
\hline <LD: below detection limit & & & \\
\hline
\end{tabular}

Units: mg/l

Table 4

comparison of heavy metal analysis from 2012 to 2020 in the sector of la quebrada el panteón.

\begin{tabular}{|lllll|}
\hline & Arsenic $(\mathrm{mg} / \mathrm{l})$ & Plum $(\mathrm{mg} / \mathrm{l})$ & Cadmium $(\mathrm{mg} / \mathrm{l})$ & Mercury $(\mathrm{mg} / \mathrm{l})$ \\
\hline year & LMP 0.1 & LMP 0.01 & LMP 0.03 & LMP 0.006 \\
\hline 2012 & 0.08 & 0.08 & 0.01 & 0.001 \\
\hline 2013 & 0.081 & 0.0054 & 0.0048 & 0.0001 \\
\hline 2014 & 0.0053 & 0.0008 & 0.0019 & 0.00068 \\
2015 & 0.01 & 0.05 & 0.02 & 0.005 \\
\hline 2016 & 3.7 & 0.031 & 0.025 & 0.0002 \\
\hline 2017 & 0.0026 & 0.3 & 0.031 & 0.005 \\
\hline 2018 & 0.03 & 0.294 & 0.036 & $<0.002$ \\
\hline 2019 & 0.2 & 0.0225 & 0.0211 & 0.0114 \\
\hline 2020 & 0.049 & $<0.001$ & 0.0075 & 0.00876 \\
\hline
\end{tabular}


Table 5

comparison of heavy metal analysis from 2012 to 2020 in the drinking water plant of santa rosa canton.

\begin{tabular}{|lllll|}
\hline & Arsenic & Plomium & Cadmium & Mercury \\
\hline year & LMP 0.01 & LMP 0.01 & LMP 0.003 & LMP 0.006 \\
\hline 2012 & 0.003 & 0.003 & 0.001 & 0.001 \\
\hline 2013 & 0.006 & 0.4 & 0.12 & 0.003 \\
\hline 2014 & 0.0082 & 0.0005 & -- & 0.0001 \\
\hline 2015 & 0.012 & 0.05 & 0.01 & 0.005 \\
\hline 2016 & 0.0014 & 0.0005 & 0.0002 & 0.001 \\
\hline 2017 & 0.0041 & $<0.0005$ & $<0.0001$ & $<0.0001$ \\
\hline 2018 & $<0.005$ & 0.0044 & 0.00031 & $<0.002$ \\
\hline 2019 & $<0.00625$ & $<0.00625$ & $<0.000625$ & $<0.001$ \\
\hline 2020 & 0.015 & $<0.001$ & 0.0106 & 0.0471 \\
\hline
\end{tabular}

Figures 


\section{GEORREFERENCIACIÓN DE LOS PUNTOS DE MUESTREO SOBRE METALES PESADOS}

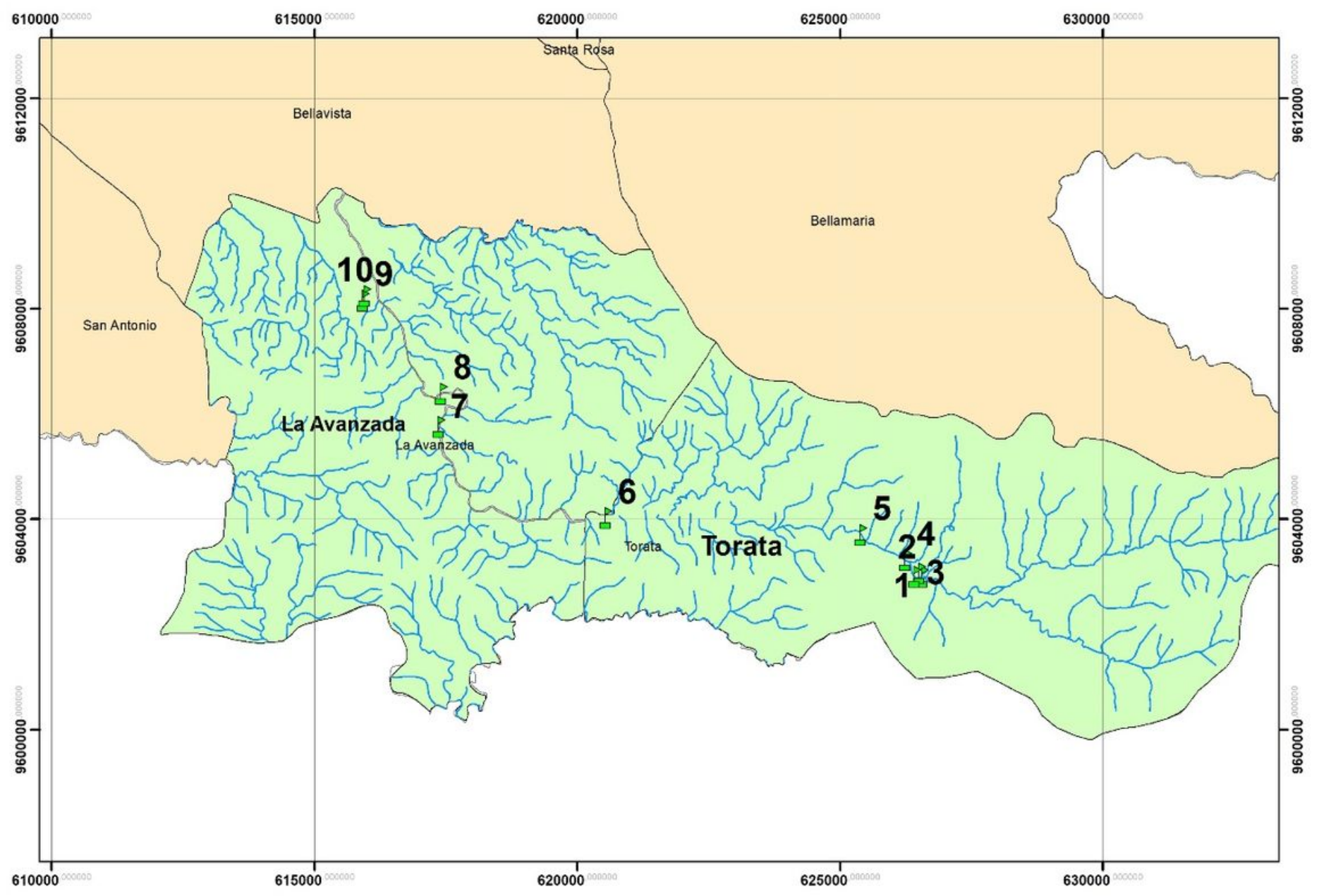

Figure 1

Georeferencing of heavy metal sampling points with ArcGIS software.. 